\title{
9. Disconnected Development Worlds: Responsibility towards Local Communities in Papua New Guinea
}

JOHN BURTON AND JOYCE ONGUGLO

\section{Introduction}

Following the publication of the Brundtland Report (UN 1987), diverse global agendas concerned with development, social and environmental sustainability, and the responsibilities of governments and corporations have come to prominence.

A concern arises that, far from being interlocked or even internally consistent, initiatives that play to particular audiences become disconnected from one another and even fail to engage properly with their original objectives. In Papua New Guinea (PNG), where we have been working, it is well known that the state has made a considerable effort to get its planning system in order (GoPNG 2009), while at the same time remaining 'off track', and achieving few of the Millennium Development Goals targets by the end of 2015 (UNDP and GoPNG 2014, Appendix 4). Equally, the Global Mining Initiative and its successor, the Mining, Minerals and Sustainable Development (MMSD) project, which ran from 2000 to 2002, were imagined as marking a new dawn in dealings between mining companies and the communities hosting mining projects. But the MMSD project did not engage with, and its final report 
(MMSD 2002) contains no reference to, the global development agenda framed by the Millennium Development Goals (MDGs), despite both being launched in the same year (see Buxton 2012).

A plausible scenario is the creation of separate 'development worlds', each with worthy aims but likely to work at cross purposes because of the different priorities of the stakeholders. Our discussion looks at three of them, centring around the issues of mine-community grievances and the social and economic development of mine-area communities, for evidence that the founding objectives are being adhered to (see Figure 9.1). Our particular focus is the position of indigenous peoples on whose land mining operations are so frequently located. The MMSD project took a special interest in this:

The post-colonial era has not seen a marked improvement in the status of indigenous peoples or their relationships to the minerals industry in many parts of the world (Danielson 2003: ix).
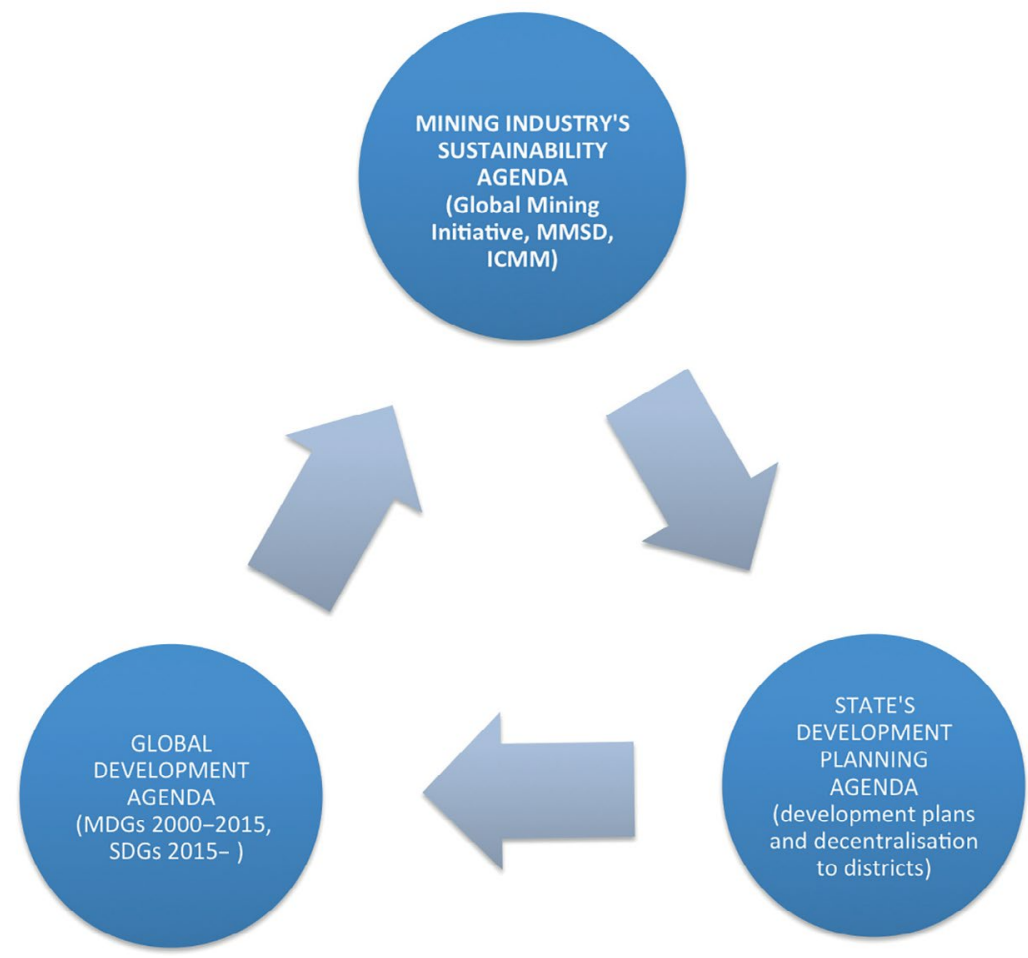

Figure 9.1 Three 'development worlds'.

Source: Authors' diagram. 
The loss of two mines in PNG were case studies: the armed conflict that closed the Panguna mine in Bougainville in 1989, majority owned by what is now Rio Tinto; and litigation brought against BHP, the then majority owner of the Ok Tedi mine, in 1994 over environmental damage, causing the exit of the company from this project in 2001 (May and Spriggs 1990; Filer 1990, 1997; Banks and Ballard 1997).

A permanent organisation was born from the MMSD project. This was the International Council on Mining and Metals (ICMM), whose membership in 2015 comprised 21 mining companies—including Rio Tinto and a restructured BHP Billiton-and 35 mining associations worldwide. The ICMM was founded with the goal of improving company performance in the mining and metals industry generally, tied to a set of sustainable development principles (see Box 9.1) and an expanding collection of guidance documents on its website that its members must follow, to make as certain as possible that social and environmental disasters like those seen in Bougainville and at Ok Tedi never happen again.

\section{Box 9.1 The ICMM sustainable development principles.}

1. Implement and maintain ethical business practices and sound systems of corporate governance.

2. Integrate sustainable development considerations within the corporate decisionmaking process.

3. Uphold fundamental human rights and respect cultures, customs and values in dealings with employees and others who are affected by our activities.

4. Implement risk management strategies based on valid data and sound science.

5. Seek continual improvement of our health and safety performance.

6. Seek continual improvement of our environmental performance.

7. Contribute to conservation of biodiversity and integrated approaches to land use planning.

8. Facilitate and encourage responsible product design, use, re-use, recycling and disposal of our products.

9. Contribute to the social, economic and institutional development of the communities in which we operate.

10. Implement effective and transparent engagement, communication and independently verified reporting arrangements with our stakeholders.

Source: www.icmm.com (version in force during the period discussed in the text). 


\section{Mining Agreements in Papua New Guinea}

Between 2007 and 2014, we have worked in communities around four mining projects in PNG-Porgera and Ok Tedi (Burton), Lihir and Hidden Valley (Burton and Onguglo). All of this work has had the central focus of evaluating the balance between social impacts and the opportunities for development that mining brings, with a special focus on whether the lives of customary landowners have seen any improvement.

In PNG, a mining agreement is the social contract entered into when a tribal people grants permission for mining on its land. The three basic elements of an agreement are:

- Free, prior and informed consent (FPIC) - the decision to allow mining and the negotiation of mining agreements are arrived at in a fair manner, following the principles of FPIC.

- Stakeholder identification-customary owners and other stakeholder groups are properly identified and written into the various sections of an agreement with accuracy, clarity and safeguards to ensure that recognition shifts do not occur over time.

- Agreement governance-processes are specified, and their costs underwritten, that ensure: benefits (royalties, compensation for loss, lease payments, employment, business spin-offs, improvements to local infrastructure, commitments to social programs) will be appropriate and divided fairly among stakeholder groups; beneficiaries receive what the agreement says without hidden transaction costs throughout the mine life; there are appropriate protections for vulnerable people; monitoring and evaluation is carried out to professional standards; and reviews are held following an agreed timetable and to the same standard as used in the original agreement-making process, or better.

A local innovation to try to achieve parts of the above is the 'development forum', first used in the negotiations for the Porgera gold mine in 198889 (Golub 2007; Filer 2008). Today, the Mining Act 1992 lays out the specifications of a forum and sets out a list of parties the mining minister should consider inviting.

At Hidden Valley, a forum was launched on 4 August 2004 (Bonai 2004). The provincial administrator, Manasupe Zurenuoc, praised the cultural appropriateness of the talks, saying that in a country such as PNG the Melanesian approach was the secret to success' (Anon. 2004a). However, 
the participants were not the six sets of communities, labelled Stakeholder Groups A-E, in the impact area that were identified in the company's social impact assessment, the document that should have guided the minister (MCG 2004a). Only Group A-represented by the mine lease landowners' Nakuwi Association-participated in them.

The process ceased to be referred to as a 'forum' after two weeks (Anon. 2004b). Sporadic media reports referred to 'talks' until a year later, when the Hidden Valley memorandum of agreement (MOA) was signed (GoPNG 2005). After the mine construction period, emergency negotiations had to be held with Group B, an omitted stakeholder group made up of the Watut River communities, when their land was impacted by the discharge of waste rock.

On these counts, the process cannot be described as a 'forum' or, for that matter, be said to reflect an inclusive, 'Melanesian' approach. What in fact happened was that decisions were made over the interests of the unrepresented stakeholder communities without their consent.

A surprising inclusion in the MOA was that the six local-level governments (LLGs) surrounding the mine in Bulolo District were allocated royalty shares amounting to 20 per cent of the total. But, here again, the body created to plan the expenditure of funds by LLGs under the Organic Law on Provincial Governments and Local-Level Governments, the Joint District Planning and Budget Priorities Committee (JDPBPC), was excluded from the agreement-making process.

In short, the MOA process was deficient: in respect of stakeholder identification because it did not properly represent the parties that should have been involved; in respect of FPIC because of the closed-door nature of the talks; and in respect of agreement governance because it handed money to government entities in a way that bypassed the coordinating body established to guide district development.

This was evident at the time, but it was not until 2015 that any agency reported on the effectiveness of the MOA. This was in the form of research privately commissioned from the PNG National Research Institute (NRI) by the Bulolo District JDPBPC. The NRI's report authors concluded that, while the financial flows to MOA parties were largely as set out by the $\mathrm{MOA}$, the systems in place for managing them were ineffective and their impacts on development were 'minimal' (Sanida et al. 2015: viii, 61). The Nakuwi Association, the link between the mine and customary 
landowners', was described as 'defective' and its business subsidiary had not submitted a tax return for ten years (ibid.: 48). This is not a surprise: the pathologies can be traced back to the 1980s, when a previous business subsidiary delivered little to its community owners (Burton 2003: 215).

These things flow on to agreement governance as a whole-the technical work of seeing that what agreements say is actually implemented. The former Department of Mining noted the isolation of the development forum from the process of planning for sustainable development' more than a decade ago (GoPNG 2003, para 2.3.1.10), and we can widen this to say that the more the state leaves most of the work of agreementmaking to local parties, the less likely it is that attention will be paid to agreement governance, frustrating the broader national and international objectives of poverty reduction.

\section{Reporting Sustainability Performance}

A major change since the millennium is that members of the ICMM undertake to report transparently on their performance each year (Principle 10). Member companies must publish a 'sustainability report' that is compliant with the Global Reporting Initiative (GRI), while nonmember companies are encouraged by peer example to do so voluntarily. All should seek to continually improve their environmental and social performance, and obtain better development outcomes for communities in mining areas.

In practice, few mining companies follow the ICMM guidelines. In the case of 33 mining companies with interests in PNG in 2013-14 (see Figure 9.2), 27 (82 per cent) did not refer to sustainability on their websites or publish a sustainability report on their PNG operations. ${ }^{1}$

\footnotetext{
1 The 33 companies are mining companies that had detectable interests in PNG in the 2014 reporting year; there may be 50 or more companies altogether. Of the 33, Barrick, Anglo American and Glencore were ICMM members. In 2011, Anglo American and Teck held 11.1 per cent and 6.8 per cent respectively of the shares of Nautilus Mining, the developer of the Solwara deep-sea mining project in PNG (Nautilus Minerals 2011). Neither mentioned this in annual sustainability reporting. Teck has since divested but Anglo American retained 5.95 per cent in 2015. Anglo American invested in a Star Mountains exploration project in 2014, but did not mention this in its report for that year (Anglo American 2015).
} 
Of the remainder, six (18 per cent) did sustainability reporting (Table 9.1). Of these, four (12 per cent) were to the standard required by ICMM or better, one (Ok Tedi Mining Limited) was non-compliant, and one (PanAust) was in the process of acquiring a PNG operation; so, while it reported on operations in Laos and Thailand, it did not do so for its (Frieda River) operation in PNG for the part of the first year in which it was involved.

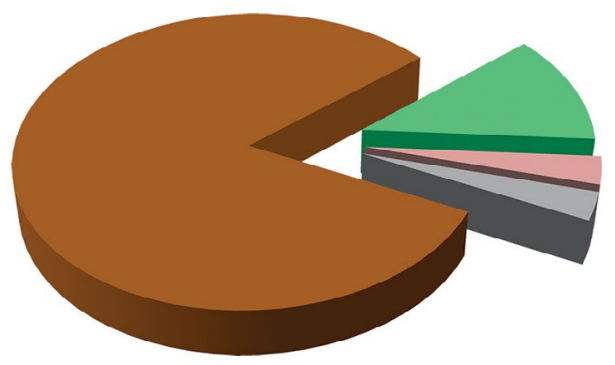

GRI G3 A+ (ICMM standard) or G4

Non-compliant

Acquisition during year

No sustainability reporting

Figure 9.2 Sustainability reporting by 33 mining companies with PNG interests in 2013-14.

Source: Authors' diagram.

Table 9.1 Disclosures in relation to mining on the lands of indigenous peoples by six mining companies undertaking sustainability reporting in PNG.

\begin{tabular}{|l|l|l|l|l|}
\hline Company & Year & Operation & $\begin{array}{l}\text { Global Reporting } \\
\text { Initiative } \\
\text { standard }\end{array}$ & $\begin{array}{l}\text { Discloses operations } \\
\text { on lands of indigenous } \\
\text { peoples? }\end{array}$ \\
\hline Barrick & $\begin{array}{l}2013 \\
\text { (cy) }\end{array}$ & Porgera & G3 & $\begin{array}{l}\text { In Australia, North America } \\
\text { and Chile, but not Porgera }\end{array}$ \\
\hline Glencore & $\begin{array}{l}2014 \\
\text { (cy) }\end{array}$ & $\begin{array}{l}\text { Frieda (to } \\
\text { August 2014) }\end{array}$ & G3 & Yes \\
\hline PanAust & $\begin{array}{l}2014 \\
\text { (cy) }\end{array}$ & $\begin{array}{l}\text { Frieda (from } \\
\text { August 2014) }\end{array}$ & G4 & Yes \\
\hline Newcrest & $\begin{array}{l}2014 \\
\text { (fy) }\end{array}$ & $\begin{array}{l}\text { Lihir, Hidden } \\
\text { Valley, Wafi }\end{array}$ & G3 & Yes \\
\hline Harmony & $\begin{array}{l}2014 \\
\text { (fy) }\end{array}$ & $\begin{array}{l}\text { Hidden Valley, } \\
\text { Wafi }\end{array}$ & G4 & Yes \\
\hline $\begin{array}{l}\text { Ok Tedi } \\
\text { Mining } \\
\text { Limited }\end{array}$ & $\begin{array}{l}2013 \\
\text { (cy) }\end{array}$ & Ok Tedi & $\begin{array}{l}\text { G4 } \\
\text { (non-compliant) }\end{array}$ & $\begin{array}{l}\text { There is a reference to a page } \\
\text { about free, prior and informed } \\
\text { consent and the Community } \\
\text { Mine Continuation Agreements, } \\
\text { but indigenous peoples are not } \\
\text { mentioned on it }\end{array}$ \\
\hline
\end{tabular}

For latest reporting period available: cy = calendar year ( 1 January-31 December); fy = financial year (1 July-30 June).

Sources: BGC (2014a); OTML (2014); Glencore (2015); NML (2015); PanAust (2015). 


\section{Indicators of Heightened Importance to Indigenous Peoples}

As noted already, all mining in PNG takes places on the customary land of tribal landowners. What content is there in GRI reporting that might help raise the alarm over incipient conflicts or the grievances that landowners may have over mine operations?

The GRI framework requires that organisations address a standard set of indicators - 79 at the G3 standard and 91 at the newer G4 standardplus an additional 11 Mining and Metals Sector Supplement (MMSS) indicators for mining companies (GRI 2010). A subset of the indicators are of heightened importance to local communities and deal with human rights, grievances and resettlement: HR1, HR9, MM5, MM6, MM7 and MM9 (and HR12 in the G4 standard) (see Table 9.2). Four indicators specifically refer to indigenous people. An immediate difficulty is that not all of the six reporting companies acknowledge that they run mines in PNG on the territories of indigenous peoples.

\section{Digression: Who Are Indigenous Peoples?}

\section{What factors define an individual or group as being 'indigenous'?}

The special status of indigenous peoples arose in the context of the colonial occupation of tribal lands, though scant progress was achieved prior to the advent of the post-war international institutions. Thus Chief Deskaheh (1873-1925) led a delegation of Six Nations Iroquois, the largest First Nation band in Canada, to Geneva in 1923, helped by the Bureau International pour la Défense des Indigènes, but was blocked from making a formal presentation at the League of Nations by Britain, the United States and Canada, all worried by the wider implications (Smith 2000; Niezen 2003: 31-5). Once the United Nations (UN) came into existence, the focus in respect of subject peoples in their own lands was decolonisation. Tribal peoples within larger settler nations still struggled for self-determination, arguably bringing into being 'indigenous peoples' as a category distinct from other subject peoples by virtue of being ethnic minorities. Definitional issues of this nature, however, were resolved by the UN Special Rapporteur José Martínez Cobo in a multivolume study in the 1980s (Box 9.2). This study informed two subsequent international 
agreements: the International Labour Organization's Convention No. 169, adopted in 1989, and the UN Declaration on the Rights of Indigenous Peoples, adopted by the General Assembly in 2007.

\section{Box 9.2 Definition of Indigenous people by the UN Special} Rapporteur José R. Martínez Cobo.

379. Indigenous communities, peoples and nations are those which, having a historical continuity with pre-invasion and pre-colonial societies that developed on their territories, consider themselves distinct from other sectors of the societies now prevailing in those territories, or parts of them. They form at present non-dominant sectors of society and are determined to preserve, develop and transmit to future generations their ancestral territories, and their ethnic identity, as the basis of their continued existence as peoples, in accordance with their own cultural patterns, social institutions and legal systems.

380. This historical continuity may consist of the continuation, for an extended period reaching into the present, of one or more of the following factors:
a. Occupation of ancestral lands, or at least of part of them;
b. Common ancestry with the original occupants of these lands;
c. Culture in general, or in specific manifestations (such as religion, living under a tribal system, membership of an indigenous community, dress, means of livelihood, life-style, etc.);
d. Language (whether used as the only language, as mother-tongue, as the habitual means of communication at home or in the family, or as the main, preferred, habitual, general or normal language);
e. Residence in certain parts of the country, or in certain regions of the world;
f. Other relevant factors.

381. On an individual basis, an indigenous person is one who belongs to these indigenous populations through self-identification as indigenous (group consciousness) and is recognized and accepted by these populations as one of its members (acceptance by the group).

Source: Martínez Cobo (1987).

In another example of disconnection between the 'development worlds', the mining industry (Danielson 2003; ICMM 2010) and global development agendas (Caruso et al. 2003; Anaya 2011) have both embraced the need for special care when indigenous peoples are involved, but the Pacific island states as a bloc-PNG, Solomon Islands, Vanuatu, Fiji, Nauru, Palau, Marshall Islands, Tonga, Tuvalu, Kiribati-have not. They were absent from the UN General Assembly at the time of the vote on the Declaration on the Rights of Indigenous Peoples.

More pointedly, a PNG Department of Mineral Policy and Geohazards Management presentation explained it would be 'wrongful' for a legislative amendment to give effect to the Declaration on the Rights of Indigenous Peoples within the Mining Act, because PNG was not among the parties 
that had adopted it (GoPNG 2012). This creates a potential consultation gap in respect of mining on tribal lands. The development forum has come into play in PNG prior to the granting of mining leases but this has given rise to the paradox of state institutions handing most of the work of agreement-making to local parties-empowering indigenous landowners-yet propped up by an official position that, logically, denies their existence.

On Lihir Island, the mining lease is wholly on 'ancestral land' and royalty is calculated and paid on the basis of its customary ownership by matrilineal clans. Indeed, ICMM's Good Practice Guide (2010) was developed by experts from the Centre for Social Responsibility in Mining at the University of Queensland with the collaboration of the mine's operator (see also Macintyre 2007).

In 2010, the mine was acquired by Newcrest Mining Limited. The company was specific in using one criterion, that of 'non-dominant sectors of society' (paragraph 379 in Box 9.2), to rule that its PNG operations did not involve indigenous people:

On the basis of this definition, it is only Newcrest's Australian operations where issues of specific Indigenous rights arise. Community relation issues with regards to Indonesia and Papua New Guinea operations are reported elsewhere in this report. (NML 2011: 57; see also NML 2012)

Barrick became the operator of the Porgera mine in 2006. Its position on indigenous people reads as follows:

Barrick endorses the ICMM Position Statement on Indigenous Peoples and Mining, which includes specific commitments and obligations related to Free Prior and Informed Consent (FPIC). Barrick is committed to implementing the Position Statement globally. (BGC 2013: 29)

But though successive sustainability reports show that Barrick considers communities in Chile, Australia and North America to be indigenous, it does not include the Ipili people of Porgera, even though land issues are handled through Ipili agents empowered under a section of PNG's Land Act that deals with customary land (Golub 2007). 
In the two cases, a single one of the special rapporteur's criteria was used to trump the full set. In reality, all landowners in PNG fit the overall definition: they occupy their ancestral lands; they are distinguished by specific customs setting them apart from their neighbours; they speak their own language as the habitual means of communication within the community; they reside in 'certain parts of the country', namely on their tribal territories; and they transmit these 'to future generations ... in accordance with their own ... legal systems', not state ones.

In the 2012 reporting year, perhaps in response to a draft of this paper circulated after the Nouméa conference in November 2011 (see Chapter 1, this volume), Newcrest (NML 2013: 62) began counting its PNG landowners as indigenous people. Barrick did not follow suit.

\section{Sustainability Reporting Continued}

A good test of whether the mining industry agenda is on track with its founding objectives is to weigh up whether company disclosures can provide an alert for the kinds of mine-community grievances and conflicts that can lead companies to 'lose the mine'.

We evaluate the companies in Table 9.2 on the way they reported the previously mentioned indicators in 2009-10, before the Nouméa conference, and again in 2013-14. Two of the companies began using the newer GRI G4 standard in the second period, which meant that a new indicator (HR12) was added for them, relating to the handling of grievances. In both periods, the most recent available report was examined, depending on the reporting cycles of the organisations.

The significance of claiming not to deal with indigenous people may be seen in the manner in which sustainability reporting is curtailed. Table 9.2 shows that in the earlier period none of the companies acknowledged the presence of indigenous people, making four indicators unreportable. In the later period, two now did so, but the commonest answer to the indicators about disputes was to say there were none. This is not really believable in PNG: there is always something to report, whether a minor grievance or something more serious. 
Table 9.2 Seven Global Reporting Initiative indicators of heightened importance to local communities and indigenous peoples, for the Lihir, Hidden Valley, Porgera and Ok Tedi mines, 2009-10 and 2013-14.

\begin{tabular}{|c|c|c|}
\hline \multirow[t]{3}{*}{ HR1 } & \multicolumn{2}{|c|}{$\begin{array}{l}\text { Percentage and total number of significant investment agreements that } \\
\text { include human rights clauses or that have undergone human rights screening. }\end{array}$} \\
\hline & $2009-10$ & $\begin{array}{l}\text { LGL: not addressed, Newcrest: not addressed, Harmony: } \\
\text { indicator not reported, Barrick: globally reported-cannot } \\
\text { disaggregate Porgera, OTML: (non-GRI). }\end{array}$ \\
\hline & $2013-14$ & $\begin{array}{l}\text { Newcrest: 'human rights [not yet screened] in investment } \\
\text { agreements', Harmony: indicator not reported, Barrick: uses } \\
\text { TRACE International anti-corruption screening system, OTML: } \\
\text { indicator omitted. }\end{array}$ \\
\hline \multirow[t]{3}{*}{ HR9 } & \multicolumn{2}{|c|}{$\begin{array}{l}\text { Total number of incidents of violations involving rights of indigenous people } \\
\text { and actions taken. }\end{array}$} \\
\hline & $2009-10$ & $\begin{array}{l}\text { LGL: } \bullet+\text { 'No incidents', Newcrest: •, Harmony: •, Barrick: •, } \\
\text { OTML: (non-GRI). }\end{array}$ \\
\hline & $2013-14$ & $\begin{array}{l}\text { Newcrest: 'No incidents [involving the Company] ... The } \\
\text { Company, on occasion, has been impacted by intra-communal } \\
\text { tensions in the surrounding communities', Harmony: } \bullet \text { indicator } \\
\text { not reported, Barrick: } \bullet \text {, OTML: } \bullet \text { indicator omitted. }\end{array}$ \\
\hline \multirow[t]{3}{*}{ MM5 } & \multicolumn{2}{|c|}{$\begin{array}{l}\text { Total number of operations taking place in or adjacent to indigenous peoples' } \\
\text { territories, and number and percentage of operations or sites where there are } \\
\text { formal agreements with indigenous peoples' communities. }\end{array}$} \\
\hline & $2009-10$ & $\begin{array}{l}\text { LGL: •, Newcrest: •, Harmony: •, Barrick: •, OTML: (non- } \\
\text { GRI). }\end{array}$ \\
\hline & 2013-14 & $\begin{array}{l}\text { Newcrest: } \bullet \text { correctly reported. Harmony: } \bullet \text { correctly reported, } \\
\text { Barrick: } \bullet \text {, OTML: } \bullet \text { discussion omits indigenous people. }\end{array}$ \\
\hline \multirow[t]{3}{*}{ MM6 } & \multicolumn{2}{|c|}{$\begin{array}{l}\text { Number and description of significant disputes relating to land use, } \\
\text { customary rights of local communities and indigenous peoples. }\end{array}$} \\
\hline & $2009-10$ & $\begin{array}{l}\text { LGL: } \bullet \text {, Newcrest: } \bullet+\text { 'Union of Watut River Communities } \\
\text { published a list of claims', Harmony: } \bullet \text {, Barrick: } \bullet \text {, OTML: (non- } \\
\text { GRI). }\end{array}$ \\
\hline & 2013-14 & $\begin{array}{l}\text { Newcrest: '2 significant disputes' (at Lihir only), Harmony: } \\
\text { 'There were no disputes during the year', Barrick: } \bullet \text {, OTML: } \\
\text { correctly reported. }\end{array}$ \\
\hline \multirow[t]{3}{*}{ MM7 } & \multicolumn{2}{|c|}{$\begin{array}{l}\text { The extent to which grievance mechanisms were used to resolve disputes } \\
\text { relating to land use, customary rights of local communities and indigenous } \\
\text { peoples, and the outcomes. }\end{array}$} \\
\hline & 2009-10 & 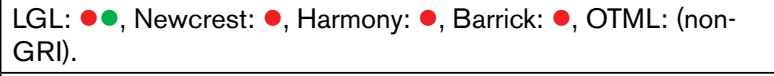 \\
\hline & $2013-14$ & $\begin{array}{l}\text { Newcrest: } \bullet \text { Lihir-correctly reported, Hidden Valley-'total of } \\
276 \text { grievances were received across Hidden Valley, Wafi- } \\
\text { Golpu and exploration operations', Harmony: } \bullet \text { indicator not } \\
\text { addressed-see HR12, Barrick: •, OTML: } \bullet \text { correctly reported. }\end{array}$ \\
\hline
\end{tabular}




\begin{tabular}{|l|l|l|}
\hline MM9 & \multicolumn{2}{|l|}{$\begin{array}{l}\text { Sites where resettlements took place, the number of households resettled in } \\
\text { each, and how their livelihoods were affected in the process. }\end{array}$} \\
\cline { 2 - 3 } & 2009-10 & $\begin{array}{l}\text { LGL: not addressed, Newcrest: 'one instance of resettlement', } \\
\text { Harmony: indicator not reported, Barrick: not addressed, } \\
\text { XStrata: 'In 2009, we resettled 116 households in four } \\
\text { locations', OTML: (non-GRI). }\end{array}$ \\
\cline { 2 - 3 } & 2013-14 & $\begin{array}{l}\text { Newcrest: correctly reported, Harmony: indicator not reported, } \\
\text { Barrick: resettlement under review, OTML: correctly reported. }\end{array}$ \\
\hline $\begin{array}{l}\text { HR12 } \\
\text { (GRI G4 } \\
\text { only) }\end{array}$ & $\begin{array}{l}\text { Number of grievances about human rights impacts filed, addressed and } \\
\text { resolved through formal grievance mechanisms. }\end{array}$ \\
\cline { 2 - 3 } & $2013-14$ & $\begin{array}{l}\text { Harmony: 'illegal strike activity occurred in March 2014, when } \\
\text { six days were lost due to grievances', OTML: indicator not } \\
\text { reported. }\end{array}$ \\
\hline
\end{tabular}

$\mathrm{LGL}=$ Lihir Gold Limited, OTML $=$ Ok Tedi Mining Limited. LGL merged with Newcrest in mid2010.

Indigenous people: $\bullet=$ recognised $\bullet=$ not recognised $\bullet=$ unclear.

Sources: LGL (2010); HGMC (2010, 2014); BGC (2011, 2014a); NML (2011, 2015); OTML (2012a, 2012b, 2014).

\section{Lihir}

Lihir Gold Limited (LGL) was one of the reporters saying it had 'no incidents' in 2009 (LGL 2010: 115), but in reality the mine had a shutdown over landowner grievances:

Australia's second-biggest listed gold producer, has been forced to shut its mine in Papua New Guinea because of landowner disputes, the firm said on Monday (Anon. 2009).

A mine shutdown is a material incident to report under HR9 and MM6. In Table 9.2, it can be seen that we score LGL for this year as both $\bullet$ and - on the MM7 indicator. LGL was one of the companies that denied the presence of indigenous people but (confusingly) had grievance policies in place that were tailored to suit dealings with indigenous people (LGL 2010: 69). The subsequent owner, Newcrest, has prevaricated about whether incidents are 'indigenous' or not. In 2012-13, it reported 'no incidents' under HR9 (NML 2014a, vol. 2: 12) when landowners shut down mine operations 'by placing the traditional gorgor plant around the mine site' (Nalu 2012). The use of gorgor shows that it was a dispute where an indigenous people pressed their case using a customary rite. It was also serious enough to affect the share price (Fitzgerald 2012). On both counts it was an HR9 incident and should have been reported as such. In 2013-14, Newcrest again said there were 'no incidents' on this indicator, but added: 
The Lihir operation is subject to a number of agreements with local landowners, which cover (among other things) compensation and other benefits, including commercial opportunities related to land ownership. The Lihir agreements are subject to periodic review, with an ongoing review at the time of this report. In the context of the current review, the Company and landowners have outlined matters that they would like addressed within the review, including the implementation of projects under the agreements, compensation payments (including distribution of benefits among landowners), the impacts of the mine and the impact of certain practices on the mine operations. These matters will be advanced as part of the ongoing Lihir agreements review. (NML 2015, vol. 2: 19)

This was a long-winded way of avoiding saying anything of substance. In reality, an impasse had been reached in reviewing agreements signed in 1995 and 2007. The Lihir Mine Area Landowners Association (LMALA) was reported as being 'angry' (Anon. 2014a) and had described a deal between the provincial and local-level governments 'as illegal' (Anon. 2014b). In mid-year, the company reported 'receiving threats' from LMALA to shut the mine (Anon. 2014c). In August and October 2014, a 'rebel group' erected roadblocks at the North Kapit stockpile. On the one hand, Newcrest said that it only dealt with LMALA, but on the other it facilitated a K6 million finance deal with the dissident group (Anon. 2014d).

To not report the incidents was to follow a very pedantic reading of HR9 on the grounds that it was unproven that the mining company had violated indigenous rights. Delayed (or cancelled) Bougainville Copper Agreement reviews were a key factor leading to conflict at Panguna in 1988-89 (see May and Spriggs 1990; Oliver 1991; also Chapter 12, this volume), and observers with long memories also recall that the present governor of New Ireland Province, where Lihir is located, said in 1986 that Lihirians were living in a 'sociological time-bomb' (Filer 1990: 78). To fudge the difficulties faced on Lihir must be judged imprudent.

\section{Hidden Valley}

At Hidden Valley in 2014, Harmony reported 'no disputes' under MM6 (HGMC 2014: 187), but elsewhere in the same report the company said that 'illegal strike activity occurred in March 2014, when six days were lost due to grievances' that were then handled by the Employee Representative Council (ibid.: 69). The question is, did the strike have anything to do with customary rights? 
The strike was about terms and conditions for semi-skilled workers and, after it turned violent, three employees were taken to hospital (Anon. 2014e; Keslep 2014). This was a significant incident, and Harmony correctly reported it under 'labour disputes and strikes', as well as flagging that this was relevant to the GRI's new HR12 indicator. However, Annex B of the Hidden Valley MOA, the mine's 'employment and training plan', clearly sets out that all unskilled positions are reserved for landownersthe bona fides of the latter being vouched for by the Nakuwi Associationand that landowners would have the highest priority for recruitment and training as heavy equipment operators, maintenance workers and drill and blast operators (MCG 2004b, sections 2.4, 3.2, and 3.5.1). This means that the complainants were local landowners whose jobs came into existence through their connection to the land needed for mining. They were correct to link their grievances to the principal mining agreement, whether or not they were right about the substance of them.

The strike was illegal only if legislation allowed employment contracts to outlaw industrial action, but as far as is known this was not the case. On the other hand, anyone involved in issuing threats or using violence 'to the person or property of another' in or near a workplace is likely to have been committing offences under the section 508 of the Criminal Code. It was incorrect to call the strike itself illegal.

Newcrest mentioned that it had handled 276 grievances at Hidden Valley and Wafi (a nearby exploration site) in 2013-14, 'tracking them to ensure that a resolution is ultimately reached' (NML 2015, vol. 1: 43). But this drew a veil over whether there had been a strike or a shutdown. In reporting the MM4 indicator ('total strikes and lock-outs exceeding one week'), it said in one place that there had been none in 2013-14 (ibid., vol. 2: 9), but in another that there had been one at Hidden Valley (ibid., vol. 3: 30). Cryptically, it noted in a market release that there was 'an $8 \%$ reduction in mill throughput' in the first quarter of the year (NML 2014b: 5) but it did not say why.

\section{Porgera}

In the 2009 reporting year, the Porgera Joint Venture published a 354page Porgera-specific environmental monitoring report (PJV 2010), but cast a veil over 'landowner concerns' that had prevented environmental 
sampling at various times and locations in the impact area. Actually, we know these were physical stand-offs between company staff and landowners, and therefore reportable 'incidents'.

But 'concerns' were not the half of it. Warlords were directing conflicts among well-armed factions in various parts of the Porgera Valley, including in and around the leases. Figures given in a policy document for local consumption, 'Restoring Justice', show that there were 70 killings during 2007 (Kikala et al. 2008: 5). If the population of the valley was about 35,000, this represented a spike in the homicide rate touching 200/100,000 — a rate not reported globally outside war zones (see Burton 2014).

Barrick buried this news in passages such as 'sustainable development ... may mean ... developing a greater capacity to plan for and manage the changes of modern life, including new law and order issues' in an optimistic 60page publicity report (BNL 2009). This stood in stark contrast to the realism of the 'Restoring Justice' document (Kikala et al. 2008), which preceded it by about three months, and to raw reality six weeks later when a police and defence force sweep called 'Operation Ipili' was launched 'to flush out the warlords' (Eroro 2009; Muri 2009a).

The police action targeted a section of the community living inside the boundaries of the mining lease at Porgera, which included about 7,000 recognised landowners at the time. Approximately 300 houses were destroyed in the raid, which received widespread coverage internationally and was investigated by at least four civil society groups. Barrick's 2009 Responsibility Report (BGC 2010) remained silent on the matter. The company received the maximum possible rating in the ICMM's annual 'member performance table' ${ }^{2}$ and its quality assurer wrote that the report gave 'a fair representation of Barrick's activities over the reporting period' (Bureau Veritas 2010).

Both Amnesty and Human Rights Watch took Barrick to task during the second half of 2010 (Amnesty International 2010; HRW 2011), and after this it was no longer possible to issue blandishments. Barrick's next Responsibility Report (BGC 2011) addressed their findings, conceding abuses by the company's security force. There was further coverage under the title 'Human Rights and Security at Porgera' on the company website.

2 www.icmm.com/en-gb/members/member-reporting-and-performance. 
This was promising, but it still fell short of the GRI requirements in respect of mining on the land of indigenous peoples (HR9, MM6), and there was no mention of whether, if effective grievance mechanisms (MM7) had been in place, complaints such as those affecting the security force could have been avoided.

In respect of the resettlement indicator (MM9), Barrick started a program to move customary owners to land away from the mining lease in 2006. The program was cancelled in late 2007 but Barrick said no more than that it 'works together with host governments to manage the resettlement of people that may be affected by our planned operations in a manner consistent with local laws and international best practice' (BGC 2007: 15, 2008: 15). For two years after cancelling the program, Barrick said nothing about it (or in answer to MM9), but then said that '[r] esettlement activities continued at Porgera ... in 2010’ (BGC 2011: 72).

None of this commentary would give any reader a clue that the issue of resettlement had been a running sore for years (e.g. Anon. 2002; Muri 2009 b) compounded by the (local) mismanagement of benefit streams that might have made mine-area villages pleasant to live in (Johnson 2012). At the time of the Nouméa conference, the answer to the question of what progress had been made at Porgera in respect of the ICMM objectives is that a litany of blunders at Porgera had a 20-year history of obfuscation and denial (Bonnell 1994; Filer 1999; Filer et al. 2008; Wiessner 2010; Burton 2014). Since the conference, the mine's oversight body, the Porgera Environmental Advisory Komiti, has published a report on the plight of women in Porgera (Johnson 2011), and Barrick has issued a 'framework of remediation initiatives' to help women abused by company guards (PJV and BGC 2012). This went some of the way towards completing the requirements of a grievance mechanism and has commendably undergone a recent review (BGC 2014b). It should not have been preceded by years of denial.

\section{Ok Tedi}

A joint venture led by BHP operated the Ok Tedi copper and gold mine from 1984 to 2001. After litigation by landowners (Banks and Ballard 1997), BHP divested its majority shareholding to a holding company, PNG Sustainable Development Program Ltd (SDP) in 2001. SDP's share 
was in turn nationalised in 2013 and the operator, Ok Tedi Mining Limited (OTML), is now a state-owned enterprise (see Chapter 8, this volume, for further detail).

OTML has historically disclosed information to the public in a patchy manner. In 2011, Howes and Kwa noted that 'OTML has been promising to use the internationally recognized Global Reporting Initiative (GRI) standards for some time, but has failed to do so' (Howes and Kwa 2011: 39). Its next two annual reviews were claimed to be 'prepared in accordance with the Global Reporting Initiative' (OTML 2012b: 3, 2013a: ii), but neither reported any indicators. No environment report to date (most recently OTML 2013b) has mentioned the GRI at all or reported against the more than 30 environmental indicators (34 from 2013). This is a serious omission, given Ok Tedi's place in the history of mining and the environment.

In its Annual Review 2013, general standard disclosures are finally reported and three of the indicators of Table 9.2 are correctly reported (OTML 2014: 125-9). This represents progress, as is also demonstrated by the voluminous documentation on the 'community mine continuation agreement' (CMCA) process to be found on its website, ${ }^{3}$ as published by the facilitators who led the first round of negotiations in 2006-07 (Sharp and Offor 2008; Offor and Sharp 2012), and as further reported by World Bank observers (Eftimie 2010; Popoitai and Ofosu-Amaah 2013).

In large part, the CMCA outcomes were expressed in terms of new benefits for the environmentally affected communities: spending on infrastructure, community projects and annual payments in cash. They are an intensification of activities in the Ok Tedi impact area handled by SDP and the OTML-funded Ok Tedi Development Foundation (OTDF) since 2001. But how can we tell if the infrastructure is in place, the projects work, and the CMCA communities are satisfied with their benefit shares?

SDP produced annual reports during its 12-year lifespan. These show that total spending on development projects (throughout PNG) was US\$578 million, in line with SDP's articles of association. Reports up to 2012 discuss projects and the company's strategy, but the word 'evaluation' does not make an appearance until the year of the Howes and

3 www.oktedi.com/our-corporate-social-responsibility/mine-continuation-consultation. 
Kwa report (2011). Thereafter, the 'design and rollout of an appropriate monitoring and evaluation system' for all projects was flagged for 2012 . The government then announced it would nationalise the mine (Elapa 2013), and after the single-page chief executive officer's message, the entirety of the final report is taken up by a tabulation of all the projects undertaken by SDP over 12 years (SDP 2013: 3-31). No evaluation of them was published.

As OTDF did not have a website until 2011, its activities prior to that year are unclear. Annual reports for 2011, 2012 and 2013, detailing projects undertaken, are available. A monitoring and evaluation policy was introduced in 2013 (OTDF 2014: 14), but no results had been published by the time of writing.

\section{Discussion}

Being able to talk about social and environmental sustainability is not the same as being able to show 'a marked improvement in the status of indigenous peoples' around mining projects.

In terms of the three worlds of development model (Figure 9.1), starting with the mining industry's sustainability agenda, our discussion of projects in PNG points to poor-if any-use of the new reporting tools. Devised both to warn of difficulty in a company's social and environmental performance, and to provide internal feedback, the evidence that managements understand their purpose is not convincing. Corporate media offices, the presumed source of sustainability reports, leave gaps and recast alarming accounts of protests, strikes and conflicts in impact areas in more soothing prose: 'threats' to close a mine dissolve into an 'ongoing agreements review'; a violent melee with tribal workers is diluted into 'grievances' handled by a review process; and 'warlords' on a killing spree around a mine become 'landowner concerns'. This is unlikely to alert managements, communities or the public in general before a future social or environmental crisis is triggered, any better than the failed systems in place prior to the Bougainville and Ok Tedi crises two decades ago.

The world of the state's development planning agenda intersects with this situation to the extent that the biggest stakeholder in mining is always the state. At the national level, royalties, taxes and duties are collected, planning objectives set, and funds channelled to the lower levels of government 
for implementation. But at all mining projects in PNG, observers find themselves struck by the failure of the state to use its windfall incomes to run essential services, let alone to progress its long-term objectives. Now that the Ok Tedi mine has been nationalised, we may speculate as to whether the livelihoods of the impact-area communities, and the quality of information bearing on their situation, will take a turn for the better or the worse. The state's performance in managing the Tolukuma mine, acquired in 2008, is not propitious: information on the website of Petromin, the state-owned enterprise of which the mine is a subsidiary, was not updated during the seven years of national ownership, and no financial report has been published since 2012. The mine closed in 2015.

A paradox is that it is often visitors from other parts of government who blow the whistle on service delivery failures. The director of PNG's National Research Institute went to Porgera and said afterwards that 'the local primary schools were closed ... the high school was closed ... the communities are missing out' (Howes 2012). His researcher showed that it was 'impossible to see where the money has gone' because local governance institutions did not produce financial reports (Johnson 2012: xii, 89-90). As noted, National Research Institute researchers found that development impacts around Hidden Valley were 'minimal' (Sanida et al. 2015). And, rather dramatically, during a parliamentary committee tour of Western Province, home of the Ok Tedi mine, an MP burst into tears when visiting a broken-down health centre (Alphonse 2015).

The world of the global development agenda barely intersects with this. The 2014 National Human Development Report (UNDP and GoPNG 2014) is a valiant attempt to gauge the impact of the country's resource incomes on poverty reduction. But since it concluded that PNG was 'off track' to achieve the Millennium Development Goal (MDG) targets (ibid.: Appendix 4), the answer can be given that, despite a substantial economic boost from the extractive industries, only weak gains have been made in human development. The report did not attempt a lower-level audit of progress in mining areas.

If MDG8-'global partnership for development'-or the post-2015 replacement SDG17-'partnerships for the goals'-were working properly, then the three different development worlds would have become integrated long ago, but they have not. When the Sustainable Development 
Goals ${ }^{4}$ were launched at the UN on 25 September 2015, the UN's expert panel declared a 'One World: One Sustainable Development Agenda' (UN 2013: 4; see also UNDP and GoPNG 2013). On the evidence of what we have seen, there is a great deal of work to be done even to reach the starting line.

\section{References}

Alphonse, A., 2015. 'MP Breaks Down in Shock, Shame.' Post-Courier, 25 May.

Amnesty International, 2010. Undermining Rights: Forced Evictions and Police Brutality around the Porgera Gold Mine, Papua New Guinea. London: Amnesty International.

Anaya, J., 2011. 'Report of the Special Rapporteur on the Rights of Indigenous Peoples: Extractive Industries Operating within or near Indigenous Territories, A/HRC/18/35.' New York: United Nations General Assembly.

Anglo American, 2015. Sustainable Development Report 2014. London: Anglo American plc.

Anon., 2002. 'Local Clans Call for New Site.' Post-Courier, 13 March.

__, 2004a. 'Goldfield Vows Support.' Post-Courier, 6 August.

—_, 2004b. 'Talks on Mine Work.' Post-Courier, 20 August.

___, 2009. 'Lihir Gold Says Papua New Guinea Mine Shut on Disputes.' Reuters, 26 January.

—_, 2014a. 'Discussions to Continue on Lihir Mine MOA.' The National, 4 February.

—_ 2014b. 'Owners Oppose Signing of Deal.' The National, 13 February.

—_, 2014c. 'Newcrest Confirms Threats.' The National, 18 June.

—_, 2014d. 'Stop Work Resolved.' The National, 17 October.

4 sustainabledevelopment.un. org $/$ ?page $=$ view $\&$ nr $=1021 \&$ type $=230 \&$ menu $=2059$. 
— 2014e. 'Employees Strike Halts Mine Operation.' Post-Courier, 21 March.

Banks, G. and C. Ballard (eds), 1997. The Ok Tedi Settlement: Issues, Outcomes and Implications. Canberra: The Australian National University, National Centre for Development Studies (Pacific Policy Paper 27).

BGC (Barrick Gold Corporation), 2007. Responsible Mining: 2006 Responsibility Report. Toronto: BGC.

__, 2008. Responsible Mining: 2007 Responsibility Report. Toronto: BGC.

—_, 2010. Responsible Mining: 2009 Responsibility Report. Toronto: BGC.

__, 2011. Responsible Mining: 2010 Responsibility Report. Toronto: BGC.

_ 2013. Responsible Mining: 2012 Corporate Responsibility Report. Toronto: BGC.

__, 2014a. Responsible Mining: 2013 Corporate Responsibility Report. Toronto: BGC.

— $2014 \mathrm{~b}$. 'The Porgera Joint Venture Remedy Framework: Olgeta Meri Igat Raits.' Toronto: BGC.

BNL (Barrick Niugini Ltd), 2009. 'Porgera: The Mine, Its People and the Future.' Port Moresby: BNL.

Bonai, S., 2004. 'Ministers to Launch Wau Projects.' Post-Courier, 4 August.

Bonnell, S., 1994. 'Dilemmas of Development: Social Change in Porgera, 1989-1993.' Brisbane: Subada Consulting Pty Ltd for Porgera Joint Venture.

Bureau Veritas, 2010. 'Independent Assurance Statement.' In BGC (Barrick Gold Corporation), Responsible Mining: 2009 Responsibility Report. Toronto: BGC. 
Burton, J., 2003. 'Fratricide and Inequality: Things Fall Apart in Eastern New Guinea.' Archaeology in Oceania 38: 208-216. doi.org/10.1002/ j.1834-4453.2003.tb00546.x

__, 2014. 'Agency and the "Avatar" Narrative at the Porgera Gold Mine, Papua New Guinea.' Journal de la Société des Océanistes 138139: $37-51$.

Buxton, A., 2012. MMSD+10: Reflecting on a Decade of Mining and Sustainable Development. London: International Institute for Environment and Development (Sustainable Markets Discussion Paper June 2012).

Caruso, E., M. Colchester, F. MacKay, N. Hildyard and G. Nettleton, 2003. Extracting Promises: Indigenous Peoples, Extractive Industries and the World Bank. Moreton-in-March (UK): Forest Peoples Programme. Baguio City (Philippines): Indigenous Peoples' International Centre for Policy Research and Education (Research Report 3).

Danielson, L., 2003. 'Foreword.' In Finding Common Ground: Indigenous Peoples and Their Association with the Mining Sector. London: International Institute for Environment and Development and World Business Council for Sustainable Development.

Eftimie, A., 2010. 'Engendering Mines in Development. A Promising Approach from Papua New Guinea.' Washington (DC): World Bank, Oil, Gas and Mining Policy Division (East Asia and Pacific RegionSocial Development Notes).

Elapa, J., 2013. 'Marriage Over, Says PM.' The National, 21 March.

Eroro, S., 2009. 'Porgera up in Flames.' Post-Courier, 30 April.

Filer, C., 1990. 'The Bougainville Rebellion, the Mining Industry and the Process of Social Disintegration in Papua New Guinea.' In R.J. May and M. Spriggs (eds), The Bougainville Crisis. Bathurst: Crawford House Press. doi.org/10.1080/03149099009508487

, 1997. 'The Melanesian Way of Menacing the Mining Industry.' In B. Burt and C. Clerk (eds), Environment and Development in the Pacific Islands. Canberra: The Australian National University, National Centre for Development Studies (Pacific Policy Paper 25). 
(ed.), 1999. Dilemmas of Development: The Social and Economic Impact of the Porgera Gold Mine 1989-1994. Canberra: Asia-Pacific Press (Pacific Policy Paper 34).

—, 2008. 'Development Forum in Papua New Guinea: Upsides and Downsides.' Journal of Energy and Natural Resources Law 2(6): 120-149.

Filer, C., J. Burton and G. Banks, 2008. 'The Fragmentation of Responsibilities in the Melanesian Mining Sector.' In C. O'Faircheallaigh and S. Ali (eds), Earth Matters: Indigenous Peoples, Corporate Social Responsibility and Resource Development. London: Greenleaf Publishing. doi.org/10.9774/gleaf.978-1-909493-79-7_11

Fitzgerald, B., 2012. 'Land Fight Shuts Lihir Gold Mine.' The Australian, 29 August.

Glencore, 2015. Sustainability Report 2014. Baar (Switzerland): Glencore plc.

Golub, A., 2007. 'From Agency to Agents: Forging Landowner Identities in Porgera.' In J.F. Weiner and K. Glaskin (eds), Customary Land Tenure and Registration in Australia and Papua New Guinea: Anthropological Perspectives. Canberra: ANU E Press (Asia-Pacific Environment Monograph 3).

GoPNG (Government of Papua New Guinea), 2003. Sustainable Development Policy and Sustainability Planning Framework for the Mining Sector in Papua New Guinea. Port Moresby: Department of Mining.

— 2005. 'Memorandum of Agreement Relating to the Hidden Valley Gold Project between the Independent State of Papua New Guinea; and the Morobe Provincial Government; and Morobe Consolidated Goldfields Limited; and Nakuwi Association Inc.; and the Wau Rural Local Level Government; and the Watut Rural Local Level Government; and Wau Bulolo Urban Local Level Government.' Port Moresby: Office of the State Solicitor.

—, 2009. Papua New Guinea Vision 2050. Port Moresby: National Strategic Plan Taskforce. 
, 2012. 'Presentation to Members of Parliament: Comments on the Proposed Mining (Amendment) Bill 2012.' Port Moresby: Department of Mineral Policy and Geohazards Management (PowerPoint presentation).

GRI (Global Reporting Initiative), 2010. Sustainability Reporting Guidelines \& Mining and Metals Sector Supplement. Amsterdam.

HGMC (Harmony Gold Mining Company Ltd), 2010. Sustainable Development Report 2010. Randfontein: HGMC.

—_, 2014. Integrated Annual Report 2014. Randfontein: HGMC.

Howes, S., 2012. 'Thomas Webster on Visas, Porgera, PNG Elections and the Resource Boom.' Devpolicy blogpost, 31 May. Viewed 11 June 2015 at: devpolicy.org/thomas-webster-on-visas-porgera-png-elections-and-theresource-boom 20120531/

Howes, S. and E. Kwa, 2011. Papua New Guinea Sustainable Development Program Review. Canberra: The Australian National University, Crawford School of Public Policy, Development Policy Centre. Port Moresby: Constitutional and Law Reform Commission.

HRW (Human Rights Watch), 2011. 'Gold's Costly Dividend: Human Rights Impacts of Papua New Guinea's Porgera Gold Mine.' Viewed 11 June 2015 at: www.hrw.org/en/reports/2011/02/01/gold-s-costlydividend.

ICMM (International Council on Mining and Metals), 2010. Good Practice Guide: Indigenous Peoples and Mining. London: ICMM.

Johnson, Penny, 2011. 'Scoping Project: Social Impact of the Mining Project on Women in the Porgera Area.' Canberra: Emic Consultancy for Porgera Environmental Advisory Komiti.

Johnson, Peter, 2012. 'Lode Shedding: A Case Study of the Economic Benefits to the Landowners, the Provincial Government and the State, from the Porgera Gold Mine.' Port Moresby: National Research Institute (Discussion Paper 124).

Keslep, S., 2014. 'Disgruntled Mine Workers Protest.' Post-Courier, 11 March. 
Kikala, P., I. Temu and P. Ipatas, 2008. 'Restoring Justice: Law and Justice Sector Partnerships in Enga Province, Papua New Guinea.' Port Moresby: Department of National Planning, Barrick Gold (Australia Pacific) and Enga Provincial Government.

LGL (Lihir Gold Limited), 2010. 2009 Sustainability Report. Port Moresby: LGL.

Macintyre, M., 2007. 'Informed Consent and Mining Projects: A View from Papua New Guinea.' Pacific Affairs 80: 49-65. doi.org/ $10.5509 / 200780149$

Martínez Cobo, J.R., 1987. 'Study of the Problem of Discrimination against Indigenous Populations by the Special Rapporteur $\mathrm{Mr}$ José R. Martínez Cobo. Volume V. Conclusions, Proposals and Recommendations, E/CN.4/Sub.2/1986/7/Add.4.' New York: United Nations Economic and Social Council, Commission on Human Rights, Sub-Commission on Prevention of Discrimination and Protection of Minorities.

May, R.J. and M. Spriggs (eds), 1990. The Bougainville Crisis. Bathurst: Crawford House Press.

MCG (Morobe Consolidated Goldfields Ltd), 2004a. 'Hidden Valley Project Social Impact Assessment.' Lae: MCG.

— $2004 \mathrm{~b}$. 'Hidden Valley Memorandum of Agreement: Annex B. Employment and Training Plan.' Lae: MCG.

MMSD (Mining, Minerals and Sustainable Development Project), 2002. Breaking New Ground: Mining, Minerals, and Sustainable Development. London: Earthscan.

Muri, D., 2009a. 'Crackdown: Porgera Security Ops Set to Kick Off.' The National, 6 April.

—, 2009b. 'Barrick Urged to Resettle Villagers.' The National, 9 April.

Nalu, M., 2012. 'Lihir Mine Shuts Down.' The National, 28 August.

Nautilus Minerals, 2011. 2011 Annual Report: Making Headway. Toronto: Nautilus Minerals. 
Niezen, R., 2003. The Origins of Indigenism: Human Rights and the Politics of Identity. Berkeley: University of California Press. doi.org/10.1525/ california/9780520235540.001.0001

NML (Newcrest Mining Limited), 2011. Newcrest Sustainability Report 2010. Melbourne: NML.

—_, 2012. Newcrest Sustainability Report 2011. Melbourne: NML.

—_, 2013. Newcrest Sustainability Report 2012. Melbourne: NML.

__ 2014a. Newcrest Sustainability Report 2013 (3 volumes). Melbourne: NML.

__, 2014b. Quarterly Report for the Three Months Ended 31 March 2014. Melbourne: NML.

__ 2015. Newcrest Sustainability Report 2014 (3 volumes). Melbourne: NML.

Offor, T. and B. Sharp, 2012. 'Turning a Benefit Agreement into Practical Development: A Case Study of a Papua New Guinea Development Foundation.' In M. Langton and J. Longbottom (eds), Community Futures, Legal Architecture: Foundations for Indigenous Peoples in the Global Mining Boom. Abingdon (UK): Routledge.

Oliver, D., 1991. Black Islanders: A Personal Perspective of Bougainville 1937-1991. Melbourne: Hyland House.

OTDF (Ok Tedi Development Foundation), 2014. Annual Report 2013. Tabubil (PNG): OTDF.

OTML (Ok Tedi Mining Ltd), 2012a. Annual Review 2010. Port Moresby: OTML.

__, 2012b. Annual Review 2011. Port Moresby: OTML.

__, 2013a. Annual Review 2012. Port Moresby: OTML.

—_, 2013b. Annual Environment Report FY2013. Port Moresby: OTML.

__, 2014. Annual Review 2013. Port Moresby: OTML.

PanAust, 2015. Shaping Our Future: 2014 Business Review \& Sustainability Report (2 volumes). Brisbane: PanAust Ltd. 
PJV (Porgera Joint Venture), 2010. Environmental Monitoring: 2009 Annual Report. January-December 2009. Mt Hagen (PNG): Environment Department, PJV Communities and Environment.

PJV (Porgera Joint Venture) and BGC (Barrick Gold Corporation), 2012. 'Framework of Remediation Initiatives in Response to Violence against Women in the Porgera Valley.' Port Moresby: PJV and BGC.

Popoitai, Y. and W. Ofosu-Amaah, 2013. 'Negotiating with the PNG Mining Industry for Women's Access to Resources and Voice: The Ok Tedi Mine Life Extension Negotiations for Mine Benefit Packages.' Washington (DC): World Bank Institute.

Sanida, O.O., A.A. Mako and C. Yala, 2015. 'A Review and Assessment of the Benefit-Sharing Arrangements of Large-Scale Mining Activities in Wau-Bulolo, Papua New Guinea.' Port Moresby: National Research Institute (Development Perspectives Paper 1).

SDP (PNG Sustainable Development Program Ltd), 2013. Annual Report Summary 2012. Port Moresby: SDP.

Sharp, B. and T. Offor, 2008. 'Renegotiating a PNG Compensation Agreement: Applying an Informed Consensus Approach.' Canberra: The Australian National University, Research School of Pacific and Asian Studies, Resource Management in Asia-Pacific Program (Working Paper 69).

Smith, D.B., 2000. 'Deskaheh (Levi General).' Dictionary of Canadian Biography (Volume XV, 1921-1930). University of Toronto. Viewed 11 June 2015 at: www.biographi.ca/en/bio/deskaheh_15E.html

UN (United Nations), 1987. Our Common Future: Report of the World Commission on Environment and Development. New York: UN General Assembly.

— 2013. A New Global Partnership: Eradicate Poverty and Transform Economies through Sustainable Development. New York: UN Publications.

UNDP and GoPNG (United Nations Development Programme and Government of Papua New Guinea), 2013. 'The Future We Want: Voices from the People of Papua New Guinea.' Port Moresby: UNDP and Department of National Planning and Monitoring. 
__, 2014. From Wealth to Wellbeing: Translating Resource Revenue into Sustainable Human Development. Port Moresby: UNDP and Department of National Planning and Monitoring.

Wiessner, P., 2010. 'Youths, Elders, and the Wages of War in Enga Province, Papua New Guinea.' Canberra: The Australian National University, State, Society and Governance in Melanesia Program (Discussion Paper 2010/3). 
This text is taken from Large-scale Mines and Local-level Politics: Between New Caledonia and Papua New Guinea, edited by Colin Filer and Pierre-Yves Le Meur, published 2017 by ANU Press, The Australian National University, Canberra, Australia. 